\title{
TOLERANCE MECHANISMS IN Hymenaea courbaril L. AND Jatropha curcas L. plants AS A RESPONSE TO WATER DEFICIT AND CONTAMINATION BY OIL DERIVATIVES
}

\author{
Marcelle Almeida Silva ${ }^{2 *}$, Cinthya Mirella Pacheco ${ }^{3}$, Cibele Alves Silva ${ }^{3}$, Hugo Henrique Costa \\ Nascimento $^{5}$ and Rejane Jurema Mansur Custódio Nogueira ${ }^{6}$
}

\footnotetext{
${ }^{1}$ Received on 13.10.2015 accepted for publication on 28.11.2016.

${ }^{2}$ Universidade Federal do Vale do São Francisco, Departamento de Biologia, Petrolina, Pernambuco - Brasil. E-mail: $<$ marcelle.almeida@univasf.edu.br>.

${ }^{3}$ Universidade Federal Rural de Pernambuco, Programa de Pós-Graduação em Biotecnologia, Recife, Pernambuco - Brasil. E-mail: <cinthya.m.pacheco@gmail.com>and<belinhaads@hotmail.com>.

${ }^{5}$ Universidade Federal de Alagoas, Centro de Ciências Agrárias, Rio Largo, Alagoas - Brasil. E-mail: <hugohcnascimento@gmail.com>. ${ }^{6}$ Universidade Federal Rural de Pernambuco, Departamento de Biologia, Recife, Pernambuco - Brasil. E-mail: $<$ rjmansur1@gmail.com $>$.

*Corresponding author.
}

\begin{abstract}
Accidents that occur during the transport of oil and its derivatives have been one of the primary causes of environmental pollution in recent decades. Studies on changes in plant physiology caused by these pollutants are scarce, and the effects on plant metabolism are little known. As such, the aim of the present study was to analyze the effect of soil contaminated with diesel fuel on the physiology of young Hymenaea courbaril L. and Jatropha curcas L. plants. The following variables were analyzed: gas exchanges, photosynthetic pigments, chlorophyll index (SPAD) and protoplasmic damage. The treatments used were: T0 - control (100\% of maximum soil water holding capacity - contamination-free soil), T1 and T2 (50\% of maximum soil water holding capacity + addition of $23 \mathrm{~mL}$ and $46 \mathrm{~mL}$ of diesel fuel, respectively) and two assessment times ( $3 \mathrm{~h}$ and $192 \mathrm{~h}$ after contamination). Significant differences in gas exchanges were observed for both species $3 \mathrm{~h}$ after diesel fuel application. For photosynthetic pigments and the chlorophyll index, increases were found $3 \mathrm{~h}$ and $192 \mathrm{~h}$ after imposed stress, for both species. A significant rise in electrolyte leakage was observed, more pronounced in J. curcas plants after $192 \mathrm{~h}$, for treatments $\mathrm{T} 1$ and $\mathrm{T} 2$ compared to T0. These findings show the potential of species to acclimate themselves to adverse conditions, and should be considered in recovery programs for environments degraded by oil derivatives.
\end{abstract}

Keywords: Stomatal behavior, Ddiesel fuel; Soil contamination.

MECANISMOS DE TOLERÂNCIA EM PLANTAS DE Hymenaea courbaril L. E Jatropha curcas L. EM RESPOSTA AO DEFICIT HÍDRICO E CONTAMINAÇÃO POR DERIVADOS DE PETRÓLEO

\begin{abstract}
RESUMO - Acidentes que ocorrem no processo de transporte do petróleo e de seus derivados têm sido um dos principais motivos de poluição ambiental nas últimas décadas. Pesquisas sobre alterações ocasionadas por estes poluentes na fisiologia de plantas ainda são escassos, sendo pouco conhecidos os efeitos ocasionados no metabolismo vegetal. Diante do exposto, o objetivo do presente estudo foi analisar o efeito do solo contaminado com óleo diesel na fisiologia de plantas jovens de Hymenaea courbaril L. e Jatropha curcas L. As variáveis analisadas foram: trocas gasosas, pigmentos fotossintéticos, indice de clorofila (SPAD) e danos protoplasmáticos. Os tratamentos utilizados foram: T0 - controle (100\% da capacidade máxima de retenção de água no solo - solo sem contaminação), T1 e T2 (50\% da capacidade máxima de retenção de água no solo + adição de $23 \mathrm{~mL}$ e $46 \mathrm{~mL}$ de óleo diesel, respectivamente) e 2 épocas de avaliação (3h e 192h após contaminação). Diferenças significativas foram evidenciadas após 3 h de aplicação do óleo diesel para as trocas gasosas para ambas as espécies. Para os pigmentos fotossintéticos e o indice de clorofila, foram verificados incrementos após 3 h e $192 \mathrm{~h}$ de imposição do estresse, para as duas espécies. Verificou-se elevados acréscimos para o
\end{abstract}


percentual de vazamento de eletrólitos, sendo mais pronunciando nas plantas de J. curcas, após 192h, para os tratamentos $T 1$ e T2 em relação ao tratamento TO. Estas observações evidenciam o potencial de aclimatação das espécies às condições adversas, devendo ser consideradas em programas de recuperação de ambientes degradados por contaminação com derivados de petróleo.

Palavras-chave: Comportamento estomático; Óleo diesel; Contaminação do solo.

\section{INTRODUCTION}

The industrial revolution transformed the world, changing the economy, politics, society, culture and environment. Mankind progressed with new inventions and technologies and the resulting industrialization saw pollution increase, primarily from the burning of fossil fuels which continue to drive the world economy (Aguiar et al., 2012).

In the $20^{\text {th }}$ century, the growth of the petrochemical sector saw an increase in oil production and its derivatives, including diesel fuel, widely used in modern industry for everything from propelling cars to energy generating units. However, repeated accidents during the transport of oil and its derivatives have been a major cause of environmental pollution in recent years (Araújo et al., 2015).

The oil industry engages in activities that pose a danger to the environment, since they contaminate a number of media (land, aquatic and atmospheric) with different organic compounds, triggering a set of transformations in their biota. An area impacted by these pollutants compromises the quality of the environment as a whole, restricting the use of soil and water resources (Rosa, 2006).

Furthermore, after contamination, plants can adsorb the contaminant (Tan et al., 2005), in addition to promoting changes in the physical and chemical properties of the soil (Penã-Castro et al., 2006), since soils contaminated with hydrocarbons lead to a lack of water, oxygen and nutrients (De Jong, 1980; Roy et al., 2003; Merkl et al., 2005), resulting in so-called combined or multiple stress.

Moreover, Njoku et al. (2008) warn against contamination by oil and its derivatives, since they have negative effects on ecosystems and contribute indirectly to compromising other parameters. This occurs when post-spill recovery is slow. With no vegetation, the surface of the soil is exposed to several agents, preventing the establishment of plant cover that protects the ecosystem.

Revista Árvore. 2017;41(2):e410205
In an attempt to control damage to nature, a number of decontamination methods for areas that have suffered or are suffering from contamination caused by oil and its derivatives are used, such as digging, incineration, extraction with solvent, and redox, among others.

Silva et al. (2014) studied strategies to recover areas contaminated by solid residues. These methods are ecologically appropriate when compared to existing physical and chemical techniques that pose a secondary contamination risk, thereby increasing the costs of reversing these polluting processes. For this reason, recent years have witnessed a shift to more economical methods that have less impact on the environment. In this respect, phytoremediation and bioremediation have emerged as promising alternatives to complement an array of financially viable environmental technologies (Balliana, 2015).

Mechanisms and techniques such as phytoremediation seek to minimize the impacts caused by these events. Numerous studies have been conducted in this area, but few involved Hymenaea courbaril L (jatoba). and Jatropha curcas L. (Barbados nut). This suggests that research on the performance of native species growing in diesel fuel-contaminated soil, from germination to plant development, will be of significant ecological importance, contributing to recovery plans through direct sowing.

Accordingly, the aim of the present study was to assess the effect of diesel fuel-contaminated soil on the physiology of young Hymenaea courbaril L. and Jatropha curcas L. plants submitted to water deficiency and different contamination times and the possible phytoremediation effect of these species in areas degraded by oil derivatives.

\section{MATERIALAND METHODS}

The experiment was conducted in the greenhouse of the Laboratory of Plant Physiology, Department of Biology at the Federal Rural University of Pernambuco 
(UFRPE). Seedlings used were from the species Hymenaea courbaril (jatoba) and Jatropha curcas (Barbados nut) originating from sexual propagation with seeds obtained in the municipality of Areia, located in the Brejo Paraibano microregion and the experimental campus of the Agrarian Science Center of the Federal University of Alagoas (UFAL), respectively. The soil used in the experiment was sandy-clayey-silt, classified as Dystrophic Yellow Argisol (Simões Neto et al., 2012) and was collected at the Advanced Campus of UFRPE - Experimental Sugarcane Station of Carpina (EECAC/ UFRPE), located in the municipality of Carpina, North Forest Zone of Pernambuco.

After seedlings germinated, they were selected for their health and uniform height, at two months old and approximately $22 \mathrm{~cm}$ high. They were then transferred to polyethylene pots, with a capacity for $3 \mathrm{~kg}$ of soil, one plant per pot. During the 60-day acclimation period, the pots were kept at capacity $(100 \%)$, previously determined by the gravimetric method, according to methodology described by Souza et al. (2000). The amount of diesel fuel used was based on Rezende (2006) and Silva (2006), for both percentage of water retained in the soil (50\% of Maximum Water Holding Capacity - MWHC) and the amount of oil per $\mathrm{kg}$ of soil $(46.2 \mathrm{~mL})$.

The experimental design was a factorial scheme, consisting of 2 species (H courbaril and Jatropha curcas), 3 treatments, namely T0 - control (100\% of maximum soil water holding capacity - contaminationfree soil), T1 (50\% of maximum soil water holding capacity + addition of $23 \mathrm{~mL}$ of diesel fuel per $\mathrm{kg}$ of soil) and T2s (50\% of maximum soil water holding capacity + $46.2 \mathrm{~mL}$ of diesel per $\mathrm{kg}$ of soil), in accordance with Li et al. (1997) and Muratova et al. (2003), and 2 assessment times ( 3 and $192 \mathrm{~h}$ after soil contamination), with 5 repetitions per treatment. Assessment times complied with criteria for early and late stress, that is, when the plants have yet to exhibit visible symptoms and when they start to show visible signs of toxicity, respectively.

Air temperature ( $\operatorname{Tair}^{\circ} \mathrm{C}$ ) and relative humidity $(\% \mathrm{RH})$ inside the greenhouse were measured daily. After treatments were differentiated, the mean Tair ${ }^{\circ} \mathrm{C}$ at first (3h) and second collection (192h) between 11:00 and $13: 00 \mathrm{~h}$ were $37.26^{\circ} \mathrm{C}$ and $39.24^{\circ} \mathrm{C}$, varying from $32.62^{\circ} \mathrm{C}$ to $39.34^{\circ} \mathrm{C}$ and $36.1^{\circ} \mathrm{C}$ to $40.7^{\circ} \mathrm{C}$, respectively.
The mean RH was $44 \%$ and $40 \%$, varying from $38 \%$ to $57 \%$ and $36 \%$ to $48 \%$, respectively. These high temperatures and low humidity reflect the high light intensity and evaporative demand.

Before the treatments were differentiated, the net photosynthesis rate was measured every $2 \mathrm{~h}$. After assessment, measurements were taken between 11:00h and 13:00h, the time of greatest stomatal opening (Figure 1), using a portable infrared $\mathrm{CO}_{2}$ gas analyzer (IRGA, ADC LCi Pro, Hoddesdon, UK).

To assess gas exchange, net photosynthesis (A), transpiration (E) and stomatal conductance (gs) were analyzed in mature, fully expanded leaves, located in the upper third of the plants, using the portable infrared $\mathrm{CO}_{2}$ analyzer described above.

The chlorophyll index of the leaves was measured 30 minutes before gas exchanges using the SPAD-502 portable chlorophyll meter (Minolta Camera Co, Osaka, Japan). Ten readings were carried out in the leaves used for gas exchanges.

These same leaves were collected to determine photosynthetic pigment contents. Readings were conducted in a spectrophotometer, at wavelengths of $662 \mathrm{~nm}, 645 \mathrm{~nm}$ and $470 \mathrm{~nm}$ (extractor: pure acetone), to determine chlorophyll $a, b$ and carotenoids, respectively, according to methodology described by Lichtenthaler and Buschmann (2001).

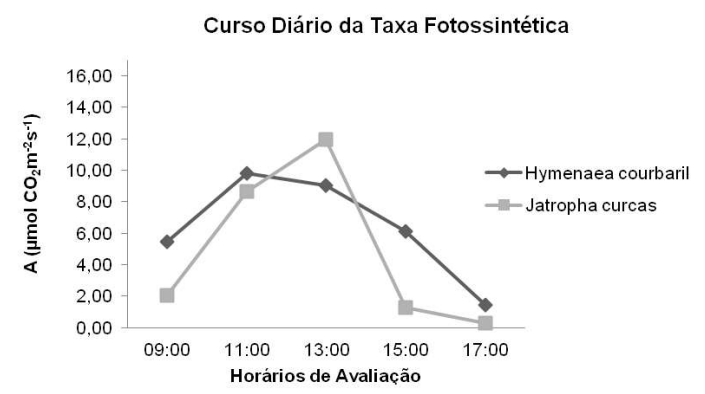

Figure 1 - Diurnal course of net photosynthetic rate of young plants of Jatobá (Hymenaea courbaril L.) and Pinhão-Manso (Jatropha curcas L.) grown in a greenhouse.

Figura 1 - Curso diário da taxa de fotossíntese liquida de plantas jovens de jatobá (Hymenaea courbaril L.) e Pinhão-Manso (Jatropha curcas L.) cultivadas em casa de vegetação.

Revista Árvore. 2017;41(2):e410205 
The degree of membrane integrity was estimated by electrolyte leakage analysis, as per Alves et al. 2009, with changes. Although the authors used $100 \mathrm{mg}$ of fresh mass, in this study 10 discs of leaf fresh mass with an area of $0.5 \mathrm{~cm}^{2}$ were employed. The percentage of electrolyte leakage, proportional to plasma membrane damage, was estimated by the following formula:

\section{$\% \mathrm{MD}(\mathrm{C} 1 / \mathrm{C} 2) \times 100$}

where \%MD is percentage membrane damage; $\mathrm{C} 1$ electrical conductivity of the extract (after incubation in a water bath at $25^{\circ} \mathrm{C}$ for $24 \mathrm{~h}$ ) and C2 electrical conductivity of the extract (after incubation in a water bath at $100^{\circ} \mathrm{C}$ for $1 \mathrm{~h}$ ).

The data obtained were submitted to analysis of variance (ANOVA) and the means compared by Tukey's test at $5 \%$ probability, using the Assistat 7.5 beta software (2008).

\section{RESULTS}

Analysis of gas exchanges for $H$. courbaril and $J$. curcas plants shows that after $3 \mathrm{~h}$ of imposed stress, the net photosynthesis rate (A), transpiration (E) and stomatal conductance (gs) exhibited similar behavior, with significant increases in gas exchanges (A, E and gs) in treatments $\mathrm{T} 1$ and T2, for H. courbaril and J. curcas, of $127 \%$ and $169 \%, 96.24 \%$ and $190 \%$, and $401.5 \%$ and $651.87 \%$, respectively, in relation to controls (T0). Even though plants showed high rates for these variables in the first hours after stress application, stomatal closing was inevitable ( stomatal conductance $=0 \mathrm{~mol} \mathrm{H} \mathrm{O}_{2} \mathrm{O} \cdot \mathrm{m}^{-2} \cdot \mathrm{s}^{-1}$ ), occurring after $192 \mathrm{~h}$ for the same treatments. The following values were obtained for the species $H$. courbaril and J. curcas: $0.1797 \mu \mathrm{mol}$ of $\mathrm{CO}_{2} \cdot \mathrm{m}^{-1} \cdot \mathrm{s}^{-1}$ and $0.4477 \mu \mathrm{mol}$ of $\mathrm{CO}_{2} \cdot \mathrm{m}^{-1} \cdot \mathrm{s}^{-1}$ and $0.6602 \mu \mathrm{mol}$ of $\mathrm{CO}_{2} \cdot \mathrm{m}^{-1} \cdot \mathrm{s}^{-1}$ and $0.3495 \mu \mathrm{mol}$ of $\mathrm{CO}_{2} \cdot \mathrm{m}^{-1} \cdot \mathrm{s}^{-1}$ for photosynthesis; $0.3395 \mathrm{mmol}$ of $\mathrm{H}_{2} \mathrm{O} \cdot \mathrm{m}^{-1} \cdot \mathrm{s}^{-1}$ and $0.1764 \mathrm{mmol}$ of $\mathrm{H}_{2} \mathrm{O} \cdot \mathrm{m}^{-1} \cdot \mathrm{s}^{-1}$ and $0.2016 \mathrm{mmol}$ of $\mathrm{H}_{2} \mathrm{O} \cdot \mathrm{m}^{-1} \cdot \mathrm{s}^{-1}$ and $0.2155 \mathrm{mmol}$ of $\mathrm{H}_{2} \mathrm{O} \cdot \mathrm{m}^{-1} \cdot \mathrm{s}^{-1}$ for transpiration, respectively (Figures $2 \mathrm{~A}, \mathrm{~B}, \mathrm{C}, \mathrm{D}, \mathrm{E}$ and F).

For the chlorophyll index, measured with a portable chlorophyll meter, significant differences were observed $3 \mathrm{~h}$ and $192 \mathrm{~h}$ after stress application (Figure 3). After $3 \mathrm{~h}$ of exposure to diesel fuel, $H$. courbaril plants in treatment $\mathrm{T} 1$ showed the best mean chlorophyll index (49.03), while the lowest means (44.26 and 41.30) were found in treatments T0 and T2 (Figure B), a decline of approximately $10 \%$ and $16 \%$, respectively, in relation to T1 plants. J. curcas plants exhibited no significant differences in the first hours after imposed stress (Figure 3A). The opposite was seen after $192 \mathrm{~h}$, when $H$. courbaril and $J$. curcas plants displayed significant increases in chlorophyll indices. For $H$. courbaril, a rise of $22.12 \%$ was found for treatment $\mathrm{T} 2$ compared to treatment $\mathrm{T} 0$ (Figure 3B). For J. curcas, significant differences were observed for treatment T1 (39.06) and T2 (39.10) in relation to treatment $\mathrm{T} 0$, which obtained the lowest mean (30.50) (Figure 3A).

After $3 \mathrm{~h}$ of imposed stress, no significant differences in chlorophyll $a$ were detected in any of the treatments. By contrast, after $192 \mathrm{~h} \mathrm{H}$. courbaril plants exhibited a rise in chlorophyll $a$ for treatment $\mathrm{T} 2$, with increases of around $150 \%$ in relation to treatment T0 (Figure 4B).

For chlorophyll $b$ and total chlorophyll, after $3 \mathrm{~h}$ of applied stress, only $H$. courbaril plants showed significant differences between treatments. Increases of $87.93 \%$ and $81.91 \%$, respectively, were obtained for treatment T2 compared with treatment T0. After $192 \mathrm{~h}$ $H$. courbaril and J. curcas exhibited a rise of $111.71 \%$ and $122.52 \%$ and $54.27 \%$ and $26 \%$, respectively, for chlorophyll $b$ and total chlorophyll for treatment 2 in relation to treatment $\mathrm{T} 0$ (Fig. $4 \mathrm{C}$ and D, E and F).

For carotenoids, significant differences were found for $H$. courbaril. These differences were observed after $3 \mathrm{~h}$ and $192 \mathrm{~h}$ of imposed stress, with increases of $142.20 \%$ and $81.64 \%$ for treatment T2, compared to treatment T0 (Fig. 4H). Comparison between times (3h and 192h) with respect to chlorophyll $a$ (Figure $4 \mathrm{~A}$ and B), chlorophyll $b$ (Figure 4C and D), total chlorophyll (Figure 4E and F) and carotenoids (Figure 4G and $\mathrm{H}$ ), showed a significant difference for treatment $\mathrm{T} 2$ in $H$. courbaril plants and for treatments T1 and T2 in J. curcas, which displayed a rise in chlorophyll contents of $62.54 \%, 38.01 \%$ and $45.54 \%$, respectively in relation to the first assessment. Chlorophyll $b$ and total chlorophyll behaved in a similar manner. Treatment T2 showed an increase of around $49.17 \%$ and 53.15 for $H$. courbaril and $57.26 \%$ and $78.29 \%$ and $44.13 \%$ and $55.70 \%$ for J. curcas in treatments T1 and $\mathrm{T} 2$, respectively. With respect to carotenoids, only H. courbaril exhibited significant differences for treatment times, with percentages of $97.34 \%, 55.82 \%$ and $48 \%$ for treatments $\mathrm{T} 0, \mathrm{~T} 1$ and $\mathrm{T} 2$, respectively.

In regard to protoplasmic damage, after $3 \mathrm{~h}$ of exposure to the contaminant, the species showed 


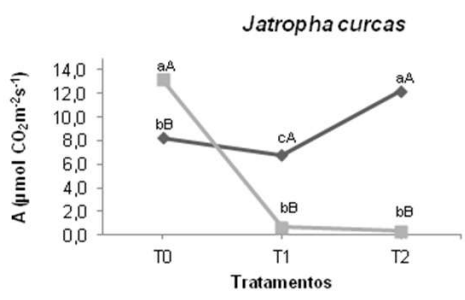

A
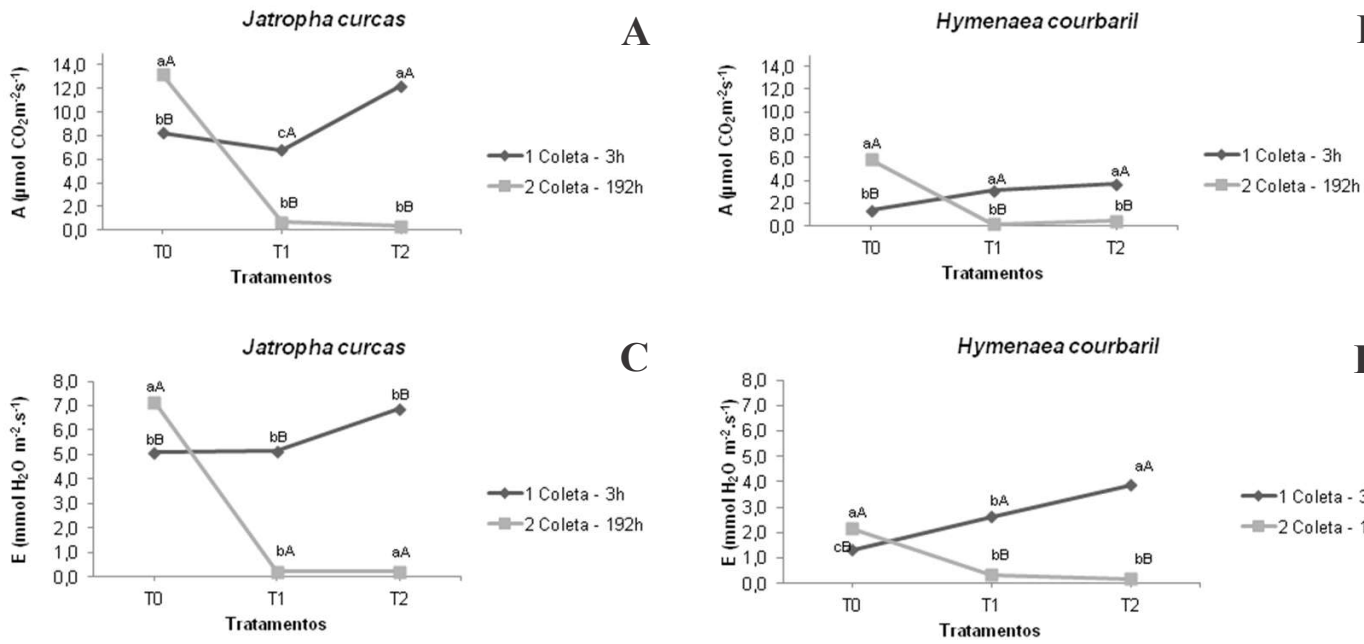

D

B

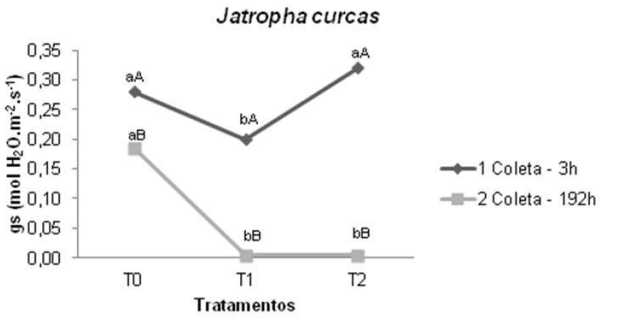

$\mathbf{E}$

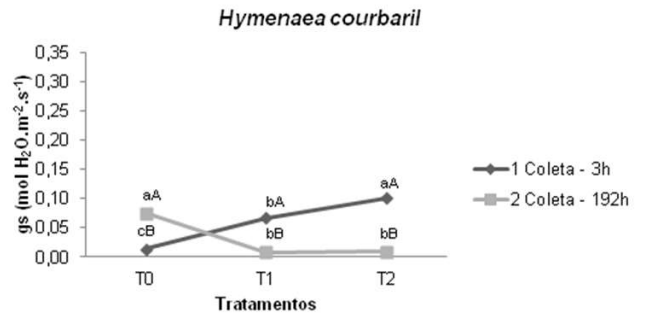

Figure 2 - Photosynthesis (E), transpiration (E) and stomatal conductance (gs) in seedlings Jatobá (Hymenaea courbaril L.) and Pinhão-Manso (Jatropha curcas L.) under different diesel oil concentrations in the soil. Equal letters, lower case compare treatments and upper case compare time of evaluate ( $3 \mathrm{~h} \mathrm{e} 192 \mathrm{~h}$ ), after contamination with diesel oil. Averages followed by the same letter do not differ by Tukey's test $(\mathrm{p}<0.05)$.

Figura 2 - Fotossíntese (A), transpiração (E) e condutância estomática (gs) em mudas de jatobá (Hymenaea courbaril L.) e Pinhão-Manso (Jatropha curcas L) submetidas a diferentes concentrações de óleo diesel no solo. Letras iguais minúsculas comparam os tratamentos e letras iguais maiúsculas comparam as épocas de avaliação (3he 192h) após contaminação com óleo diesel. Medias seguida de mesma letra não diferem entre si pelo teste Tukey $(p<0.05)$.

Jatropha curcas

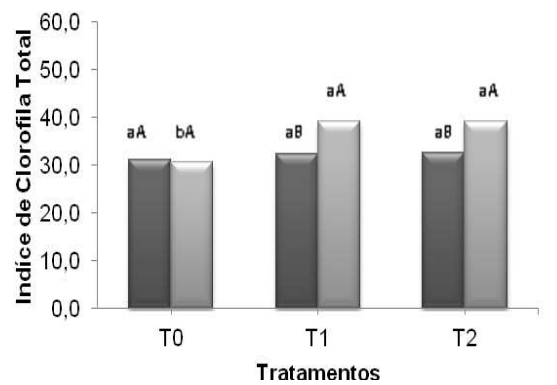

a 1 Coleta - 3h

$\square$ Coleta $-192 \mathrm{~h}$

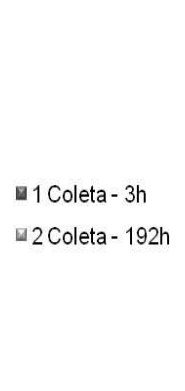

Hymenaea courbaril

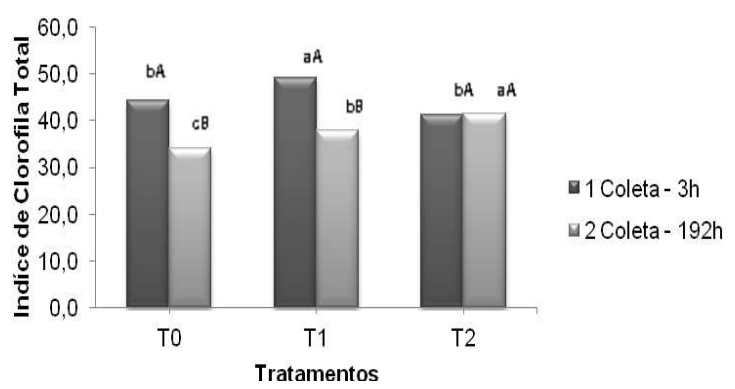

Figura 3 - Índice de clorofila SPAD (medidor portátil de clorofila-MPC) em mudas de Jatobá (Hymenaea courbaril L). e Pinhão-Manso (Jatropha curcas L.) submetidas a diferentes concentrações de óleo diesel no solo. Letras minúsculas e iguais comparam os tratamentos e letras maiúsculas e iguais comparam as épocas (3h e 192h) após contaminação com óleo diesel. Medias seguida de mesma letra não diferem entre si pelo teste Tukey $(\mathrm{p}<0.05)$.

Figure 3 - Chlorophyll index SPAD (portable measuring chlorophyll-MPC) in seedlings Jatobá (Hymenaea courbaril L.) and Pinhão-Manso (Jatropha curcas L.) under different diesel oil concentrations in the soil. Equal letters, lower case compare treatments and upper case compare time of evaluate ( 3 h e 192h), after contamination with diesel oil. Averages followed by the same letter do not differ by Tukey's test $(p<0.05)$. 

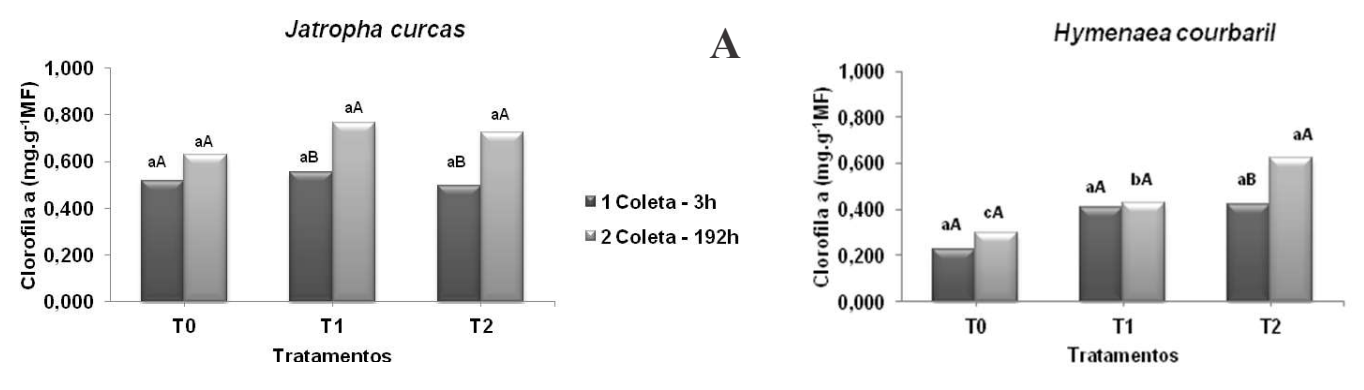

B

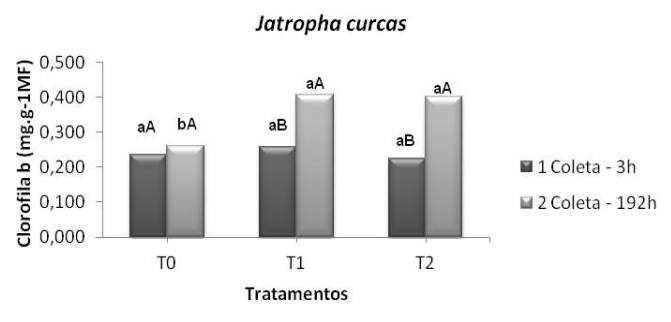

C

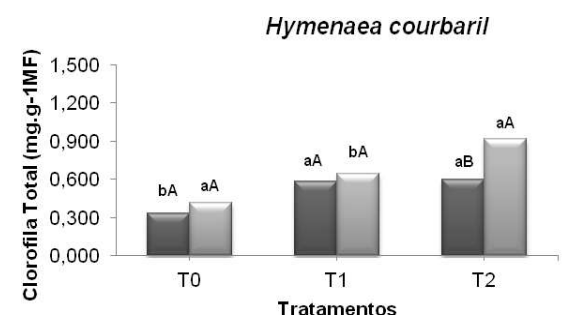

D

$\square 1$ Coleta - $3 \mathrm{~h}$

$\square 2$ Coleta- $192 \mathrm{r}$

Hymenaea courbaril

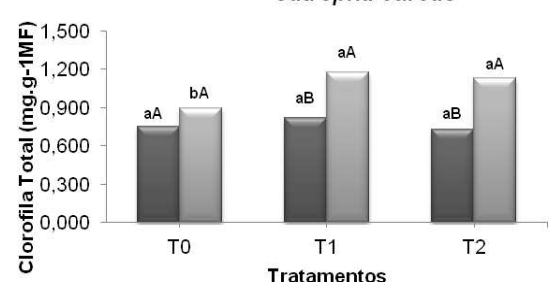

$\mathbf{E}$

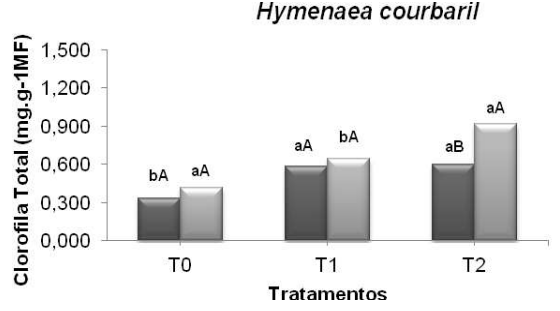

$\square 1$ Coleta- $3 \mathrm{~h}$

1 Coleta- $3 \mathrm{~h}$

$\square 2$ Coleta $-192 \mathrm{~h}$

Jatropha curcas
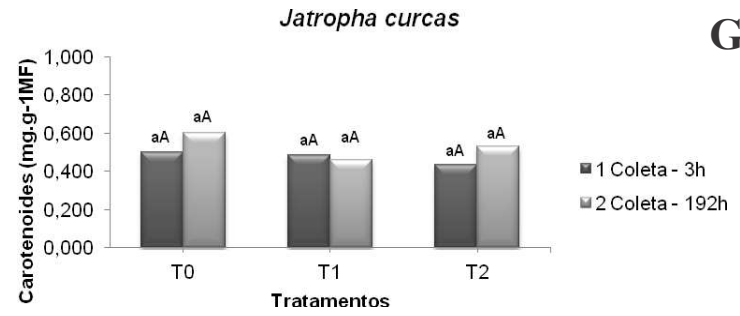

G

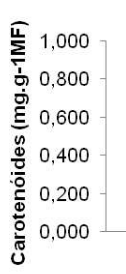

Hymenaea courbaril

$\mathbf{H}$

-1 Coleta- $3 \mathrm{~h}$

12 Coleta $-192 \mathrm{~h}$

Figure 4 - Quantification of photosynthetic pigments in seedlings Jatobá (Hymenaea courbaril L.) and Pinhão-Manso (Jatropha curcas L.) under different diesel oil concentrations in the soil. in seedlings Jatobá (Hymenaea courbaril L.) and Pinhão-Manso (Jatropha curcas L.) under different diesel oil concentrations in the soil. Equal letters, lower case compare treatments and upper case compare time of evaluate ( $3 \mathrm{~h}$ e $192 \mathrm{~h}$ ), after contamination with diesel oil. Averages followed by the same letter do not differ by Tukey's test $(\mathrm{p}<0.05)$.

Figura 4 - Quantificação dos teores de pigmentos fotossintéticos em mudas de Jatobá (Hymenaea courbaril L.) e PinhãoManso (Jatropha curcas L.) submetidas a diferentes concentrações de óleo diesel no solo. Letras minúsculas e iguais comparam os tratamentos eletras maiúsculas e iguais comparam as épocas (3h e 192h) após contaminação com óleo diesel. Medias seguida de mesma letra não diferem entre si pelo teste Tukey $(p<0.05)$.

significant differences in percentage electrolyte leakage in relation to treatment $\mathrm{T} 0$, despite treatment $\mathrm{T} 1$ plants of both species displaying higher means, albeit not significant (Figure 5). With prolonged stress, statistical differences were only observed for J. curcas plants, which exhibited increases of $90.90 \%$ and $54.48 \%$ for treatments T1 and T2 compared to T0 (Figure 5A), respectively. When times ( $3 \mathrm{~h}$ and $192 \mathrm{~h}$ ) were compared, the treatments showed a percentage rise in electrolyte leakage with prolonged stress of around $111.36 \%$ and 

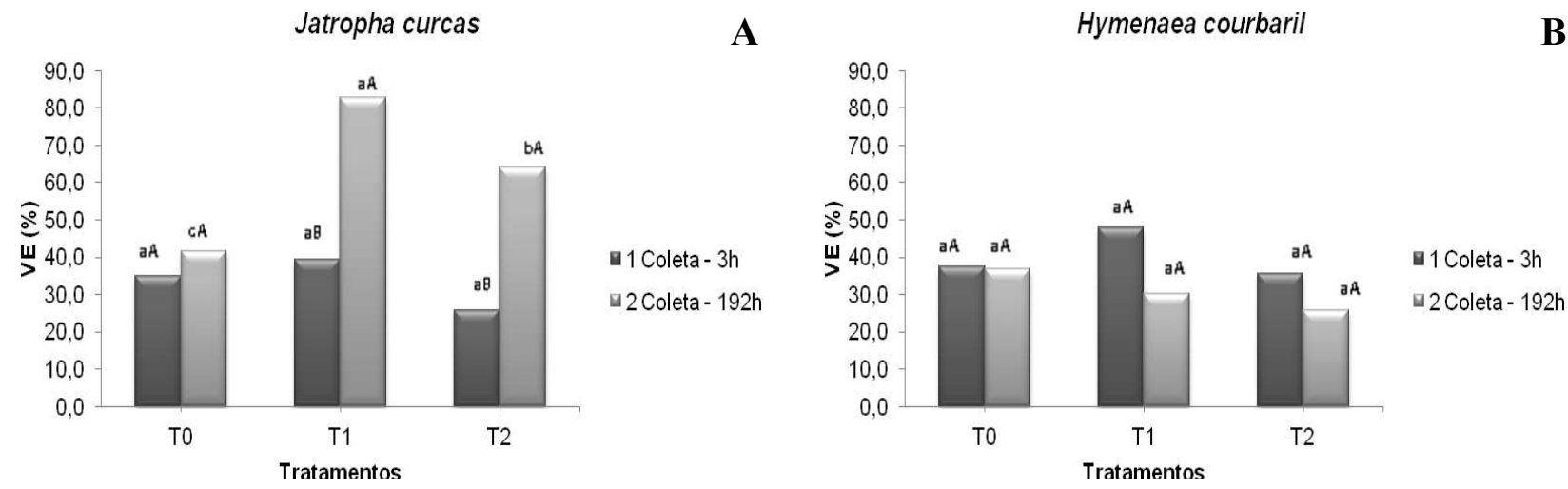

Figure 5 - Percentage of electrolyte leakage in seedlings Jatobá (Hymenaea courbaril L.) and Pinhão-Manso (Jatropha curcas L.) under different diesel oil concentrations in the soil. Equal letters, lower case compare treatments and upper case compare time of evaluate ( $3 \mathrm{~h}$ e 192h), after contamination with diesel oil. Averages followed by the same letter do not differ by Tukey's test $(\mathrm{p}<0.05)$.

Figura 5 - Percentual de vazamento de eletrólitos em mudas de Hymenaea courbaril L. (A) e Jatropha curcas L.(B) submetidas a diferentes concentrações de óleo diesel no solo. Letras minúsculas e iguais comparam os tratamentos e letras maiúsculas e iguais comparam as épocas (3h e 192h) após contaminação com óleo diesel. Medias seguida de mesma letra não diferem entre si pelo teste Tukey $(p<0.05)$.

$149.45 \%$, respectively, for $J$. curcas plants. An interesting fact is that $H$. courbaril plants, despite not differing statistically, showed higher electrolyte leakage percentages in the first $3 \mathrm{~h}$ after application of diesel oil for treatment T1 (Figure 5B). With prolonged stress (192h), these values declined, showing a possible late tolerance mechanism in these plants (Figure 5B).

\section{DISCUSSION}

It is important to underscore that control plants (T0) showed significant reductions in gas exchanges compared to the other treatments at initial assessment. This reduction may be attributed to the climatic conditions such as temperature and relative humidity $\left(37.26^{\circ} \mathrm{C}\right.$ and $44 \%$ ), respectively, at the assessment times. According to Taiz and Zeiger (2013), in natural and cultivable conditions, plants are often exposed to climatic fluctuations. While temperature and humidity become stressful in a few minutes, factors such as water availability in the soil can take days or even weeks to manifest themselves, and mineral deficiencies in the soil take months.

One possible explanation for the high photosynthetic rates in the first hours after diesel fuel application may be related to its elevated concentrations of hydrocarbons. Given that it is an oil-based fuel, composed basically of hydrocarbons, carbon atoms, hydrogen and low concentrations of sulfur, nitrogen and oxygen, and given its hydrophobic character, (Viana (2008)), diesel fuel may have made the water molecules more available to plants in the first hours, representing an obstacle between the soil/air interface. This fact provides plants with a momentary water supply, where gas exchanges are not expected to be initially affected.

However, with prolonged stress, hydrocarbons were likely adsorbed by root hairs, suppressing the amount of water adsorbed by the roots, causing water, respiratory and nutritional deficiency in plants (Baker, 1970). According to Larcher(2006), when water availability in the soil is less than that required by the plant, all metabolic processes are compromised, resulting in leaf withering and a decline in turgor pressure, paralyzing the mechanical entry of water into the cell, leading to a reduction in cell volume. The effect of low water availability on plant development depends on the magnitude and duration of stress, as well as the genetic ability of plants to respond to environmental changes (Silva and Nogueira, 2003).

Assessment of chlorophyll content in leaves is an important aspect for plant physiology studies, since it could be an indicator of leaf senescence, nitrogen nutritional status, in addition to expressing the possible changes as a response to environmental stress (Silva et al., 2016).

The results show that plants did not suffer from nitrogen $(\mathrm{N})$ deficiency, and closed their stomata to 
impede the escape of water vapor (transpiration), due to the unavailability of water absorption by the roots. Given that it contains nitrogen, the application of diesel oil increased the concentration of this element in the soil, and was absorbed by the plant. Nitrogen $(\mathrm{N})$ is an essential element, required in large amounts by plants, and a constituent of chlorophyll and many compounds, including highly mobile proteins and nucleic acids. As leaves aged, symptoms such as chlorosis (yellowing of leaves) and necrosis were observed, with consequent foliar abscission. These symptoms indicate nitrogen deficiency (Lacerda, 2006), and given that assessments were always conducted in the upper third of the leaf, no decline in the chlorophyll index was found using the portable chlorophyll meter, due to the significant mobility of this element from old to young leaves (Taiz and Zeiger, 2013).

The results demonstrate that plants showed no degradation in photosynthetic pigments. This behavior may be explained by the short experimental period. A drop in chlorophyll concentration in plants grown in soil contaminated by oil and its derivatives was observed in Canavalia ensiformes plants submitted to different doses of diesel fuel (Balliana, 2015).

However, H. courbaril and J. curcas plants showed an increase in chlorophyll $a, b$, total chlorophyll and carotenoids. Behavior similar to that observed in the present study was reported by Oliveira (2008), investigating Schinus terebinthifolius with soil from an area where an oil spill of approximately 4 million liters occurred, 700 thousand liters of which seeped into the soil. The author observed a rise in chlorophyll $a, b$ and total chlorophyll in plants growing in oilcontaminated soil.

Electrolyte leakage is directly linked to cell death, since it is triggered by ionic toxicity, which destabilizes the plasmic membrane and leads to cytoplasmic electrolyte leakage (Mengel and Kirkby, 2001). This may explain the much more evident visual symptoms (blackish spots and subsequent necrosis) in J. curcas plants compared to their $H$. courbaril counterparts.

As such, in the short term, the use of young plants instead of seeds in areas contaminated by diesel fuel was much more efficient in recovery efforts. More phytophysiology studies are needed to determine the specific effects of different contaminants on plant metabolism, in order to understand their synergetic effects.

\section{CONCLUSIONS}

Hymenaea courbaril and Jatropha curcas displayed significant alterations in gas exchanges, with an increase in means $3 \mathrm{~h}$ after diesel addition for treatments $\mathrm{T} 1$ and $\mathrm{T} 2$, and subsequent decline with prolonged stress (192h);

Soil contaminated with diesel fuel exhibited an increase in photosynthetic pigment levels and chlorophyll index for Hymenaea courbaril and Jatropha curcas plants in treatments T1 and T2, 192h after imposed stress, but these results did not reflect in higher photosynthetic rates;

Jatropha curcas plants showed more significant symptoms of leaf injury than Hymenaea courbaril plants, evidenced in the variable electrolyte leakage percentage (protoplasmic membrane damage);

All the variables studied (gas exchanges, chlorophyll index, photosynthetic pigments and electrolyte leakage) were good indicators of the degree of tolerance displayed by Hymenaeae courbaril and Jatropha curcas plants to the stress caused by diesel fuel.

\section{REFERENCES}

Aguiar CRC, Lopes BC, Barbosa MVD, Balieiro FC, Gomes MM. Fitorremediação de solos contaminados por petróleo. Revista Trópica Ciências Agrárias e Biológicas. 2012;6(1):3-9.

Alves FAL. Mecanismos fisiológicos envolvidos com a diminuição de $\mathrm{K}^{+}$em raízes de cajueiro causada por $\mathrm{NaCl}$. Revista Ciência Agronômica. 2009;40(4):588-95.

Araújo NKC, Guimarães DKS, Gondim AD, Silva DR. Avaliação da capacidade de adsorção do $\mathrm{Al}_{2} \mathrm{O}_{3}$ na remoção de benzeno. In: Anais do $5^{\circ}$ Encontro Regional de Química; $4^{\circ}$ Encontro Nacional de Química São Paulo: Blucher; 2015. p.815-820.

Baker JM. The effects of oils on plants. Environmental Pollution. 1970;1(1):27-44.

Balliana AG. Avaliação morfofisiológica de Cavanalia ensiformes (L.) DC. (FABACEAE) em substrato contaminado com óleo diesel [dissertação]. Curitiba: Universidade Federal do Paraná; 2015. 
De Jong, E. The effect of a crude oil spill on cereals. Environmental Pollution. 1980;22(3):187-96.

Larcher W. Ecofisiologia vegetal. São Carlos: Rima; 2006. 531p.

Li X, Feng Y, Sawatsky N. Importance of soil-water relations in assessing the endpoint of bioremediated soils. Plant and Soil. 1997;192:219-26.

Lichtenthaler HK, Buschmann C. Chlorophylls and carotenoids: measurement and characterization by UV-VIS spectroscopy. Current Protocols in Food Analytical Chemistry. 2001; F4.3.1-F4.3.8.

Mengel K, Kirkby E. Principles of plant nutrition. $5^{\text {th }}$.ed. Dordrecht: Kluwer Academic Publishers; 2001. 849p.

Merk1 N, Schultze-Kraft R, Infante C. Phytoremediation in the tropics - influence of heavy crude oil on root morphological characteristics of graminoids. Environmental Pollution. 2005; 138:86-91.

Muratova AY, Turkovskaya OV, Hübner T, Kuschk P. Studies of the efficacy of alfalfa and reed in the phytoremediation of hydrocarbon-polluted soil. Applied Biochemistry and Microbiology. 2003;39(6):681-8

Njoku KL, Akinola MO, Oboh BO. Germination, survival and growth of accessions of Glycine max L. (Merril) (Soybean) and Lycopersicon esculentum L. (Tomato) in crude oil polluted soil. Research Journal of Environmental Toxicology. 2008;2:77-84.

Oliveira LS, Bona C, Santos GO, Koehler HS. Crescimento de Schinus terebinthifolius Raddi (anacardiaceae) em solo contaminado com petróleo. Acta Ambiental Catarinense. 2008;5(1/2):21-33.

Penã-Castro JM, Barrera-Figu B. Isolation and identifi cation of up-regulate genes in bermudagrass roots (Cynodon dactylon L.) grown under petroleum hydrocarbon stress. Plant Science. 170(4):724-31.

Rezende IM. Efeito do solo contaminado por óleo diesel na germinação e nas plantas jovens de schinus terebinthifolius raddi (anacardiaceae) [dissertação] Curitiba: Universidade Federal do Paraná; 2006.
Rosa GS. Avaliação do potencial de espécies vegetais na fitorremediação de solos contaminados por petróleo [dissertação]. Rio de Janeiro: Universidade do Estado do Rio de Janeiro; 2006.

Roy JL, Mcgill WB, Lowen HA, Johnson RL. Relationship between water repellency and native and petroleum-derived organic carbon in soils. Journal Environmental Quality. 2003;32:583-90.

Silva EC, Nogueira RJMC. Crescimento de quatro espécies lenhosas cultivadas sob estresse hídrico em casa de vegetação. Revista Ceres. 2003;288:203-17.

Silva GR, Souza Júnior EJ, Silva WG, Ramos OR. Avaliação do desenvolvimento da espécie Citharexylum myrianthum (Tucaneiro) sobre doses de óleo diesel. In: Anais do $15^{\circ}$ Encontro Nacional de Estudantes de Engenharia Ambiental; Fórum Latino Americano de Engenharia e Sustentabilidade; Simpósio Brasileiro de Engenharia Ambiental. Brasília: UNB; 2016. p.1-7.

Silva JS, Santos SS, Gomes FGG. A biotecnologia como estratégias de reversão de áreas contaminadas por resíduos sólidos. Revista Eletrônica em Gestão, Educação e Tecnologia Ambiental. 2014;18(4):1361-70.

Simões Neto Oliveira AC, Rocha AT, Freire FJ, Freire MBGS, Nascimento CWA. Características agroindustriais da cana-de-açúcar em função da adubação fosfatada, em solos de Pernambuco. Revista Brasileira de Engenharia Agrícola e Ambiental. 2012;16:347-54.

Souza CC, Oliveira FA, Silva IF, Amorim Neto MS Avaliação de métodos de determinação de água disponível e manejo da irrigação em terra roxa sob cultivo de algodoeiro herbáceo. Revista Brasileira de Engenharia Agrícola e Ambiental. 2000;4(3)33842.

Taiz L, Zeiger E. Fisiologia vegetal. $5^{\text {a }}$.ed. Porto Alegre: Artmed; 2013.

Tan BL, Sarafis V, Beattie GAC, White IR, Darley EM. Spooner-Hart, R. Localization and movement of mineral oil in plants by fluorescence and confocal microscopy. Journal of Experimental Botany. 2005;56(420):2755-63.

Revista Árvore. 2017;41(2):e410205 
Viana FV, Correia TMB, Machado MI, Pederzolli EM, Zanella NP, Baisch P. et al. O uso da fitorremediação em área contaminada por resíduos da indústria petroquímica. Petro \& Química. 2008;8:52-6. 